\title{
PEMANFAATAN GAS BIO SEBAGAI SUMBER ENERGI PANAS DALAM PENETASAN TELUR AYAM KAMPUNG
}

\author{
(Utilization of Bio Gas as a Source of Heat Energy for Kampung \\ Chicken Hatching Eggs)
}

\author{
Raja Porkot Siregar ${ }^{1}$, Nurzainah Ginting ${ }^{2}$, Zulfikar Siregar $^{2}$
}

1. Mahasiswa Program Studi Peternakan Fakultas Pertanian Universitas Sumatera Utara 2. Staf Pengajar Program Studi Peternakan Fakultas Pertanian Universitas Sumatera Utara

\begin{abstract}
Bio gas as an alternative energy derived from animal feces can be used as a source of heat for hatching eggs. This study aims to determine the effectiveness of bio gas as a source of heat energy for hatching chicken eggs. The experiment was conducted from March 2013-May 2013, at the Livestock Group Harapan Jaya, Deli Tua district, Deli Serdang regency, North Sumatera Province. The design used split plot design (SPT) with 2 factors and 4 replications. The first factor as a main plot turning of eggs frequency $(4,6,8$ times/day) and the second factor as a sub plot heat source (electricty and bio gas) This study use 120 of chicken eggs with an average weight $(47.5 \pm 3.42 \mathrm{~g})$. The result showed that $100 \%$ of fertility turning of eggs frequency treatment, the highest mortality at $R 130 \%$, and the highest hachability at $R 392.5 \%$, for the source of heat treatment showed that $100 \%$ fertility, the highest mortality at P1 $18.33 \%$, and the highest hachability at P2 $83.33 \%$. The interaction between treatment showed that $100 \%$ fertility, the highest mortality at R1P1 30\%, and the highest hachability at R3P2 95\%. The result indicated that turning of eggs frequency treatment influence $(P>0.05)$ on mortality and hatchability, the source of heat treatment there is not influence $(P>0.05)$ on mortality and hatchability, and the result indicated that interaction between the turning of eggs frequency and the source of heat there is not influence $(P>0.05)$ on mortality and hatchability of kampung chicken hatching eggs. It can be concluded that bio gas as a source heat for kampung chicken hatching eggs.
\end{abstract}

Keywords: Electricty, Fertility, Mortality, Bio gas, hatchability.

\begin{abstract}
ABSTRAK
Gas bio sebagai energi alternatif yang berasal dari feses ternak dapat digunakan sebagai sumber panas dalam penetasan. Penelitian ini bertujuan untuk mengetahui efektifitas gas bio sebagai sumber energi panas dalam penetasan telur ayam kampung. Penelitian dilaksanakan di Kelompok Ternak Harapan Jaya, Kecamatan Deli Tua, Kabupaten Deli Serdang, Provinsi Sumatera Utara dari bulan Maret 2013 - Mei 2013. Rancangan yang dipakai dalam penelitian ini adalah rancangan petak terbagi (RPT) dengan menggunakan 2 faktor dan 4 ulangan. Faktor pertama sebagai petak utama pemutaran telur (4, 6, 8 kali/hari), faktor kedua sebagai anak petak sumber panas (listrik dan gas bio) dan Penelitian ini menggunakan 120 butir telur ayam kampung dengan bobot rata-rata $(47,5 \pm 3,42 \mathrm{~g})$. Hasil penelitian menunjukan bahwa pada perlakuan frekuensi pemutaran diperoleh fertilitas sebesar $100 \%$, mortalitas tertinggi pada R1 sebesar 30\%, dan daya tetas tertinggi pada R3 sebesar $95 \%$, sedangkan untuk perlakuan sumber panas diperoleh fertilitas $100 \%$, mortalitas tertingi pada P1 sebesar $18,33 \%$, dan daya tetas tertinggi pada P2 sebesar $83,33 \%$. Interaksi perlakuan antara frekuensi pemutaran dan sumber panas menunjukkan fertilitas sebesar 100\%, mortalitas tertinggi pada R1P1 sebesar 30\%, dan daya tetas tertinggi pada R3P2 sebesar 95\%. Hasil penelitian menunjukkan bahwa perlakuan frekuensi pemutaran telur memberikan hasil yang berbeda nyata $(\mathrm{P}>0,05)$ terhadap mortalitas dan daya tetas, sedangkan perlakuan sumber panas pememberikan hasil yang tidak berbeda nyata $(\mathrm{P}>0,05)$ terhadap mortalitas dan daya tetas. Hasil penelitian menunjukkan bahwa interaksi antara frekuensi pemutaran dan sumber panas dalam penetasan tidak berbeda nyata $(\mathrm{P}>0,05)$ terhadap mortalitas dan daya tetas telur ayam kampung. Dapat disimpulkan bahwa gas bio dapat dijadikan sebagai energi alternatif panas dalam penetasan telur ayam kampung.
\end{abstract}

Kata Kunci : Listrik, Fertilitas, Mortalitas, Gas bio, Daya Tetas 


\section{PENDAHULUAN}

Peternakan merupakan sub sektor pertanian yang berperan sangat penting dalam penyediaan kebutuhan pangan khususnya protein hewani. Kebutuhan protein hewani terus meningkat seiring dengan pertambahan penduduk dan meningkatnya kesadaran masyarakat akan pentingnya zat gizi. Usaha ternak unggas merupakan salah satu upaya memenuhi kebutuhan protein hewani, diantaranya adalah ayam kampung.

Ayam kampung merupakan ayam asli Indonesia yang telah lama dipelihara dan dikembangkan oleh masyarakat, terutama yang tinggal di pelosok-pelosok pedesaan. Ayam kampung telah beradaptasi dengan kondisi lingkungan pemeliharaan yang sederhana, dan menghasilkan kualitas dan kuantitas produksi yang cukup baik (Suprijatna, 2005).

Proses penetasan telur khususnya ayam kampung telah berkembang, baik secara tradisional yang menggunakan sekam padi maupun lampu minyak bahkan sampai cara modern yaitu menggunakan mesin tetas tenaga listrik. Pemakaian listrik semakin lama semakin meningkat seiring dengan meningkatnya jumlah penduduk sementara bahan baku untuk menghasilkan listrik misalnya minyak bumi yaitu solar cadangannya semakin berkurang. Bila keadaan ini terus berlanjut maka akan berakibat pada berkurangnya pasokan listrik sehingga kemungkinan akan berdampak negatif kepada unit usaha seperti penetasan telur, oleh karena itu diperlukan suatu alternatif sumber energi untuk penetasan telur misalnya gas bio $\left(\mathrm{CH}_{4}\right)$.

Gas bio merupakan salah satu sumber energi terbarukan yang berasal dari limbah organik, misalnya limbah asal peternakan. Gas bio mampu menghasilkan energi yang baik, apinya berwarna biru, tidak berbau dan tidak berasap oleh karena itu diharapkan gas bio dapat dijadikan sebagai sumber energi, misalnya pada penetasan telur. Gas bio dapat diolah menjadi panas dengan perbandingan $1 \mathrm{~m}^{3}$ gas bio sebagai bahan bakar dapat membangkitkan listrik sebesar 1,25 Kw (Nukulchai et al., 1985).

\section{BAHAN DAN METODE PENELITIAN}

\section{Lokasi dan Waktu Penelitian}

Penelitian dilaksanakan di Kelompok Ternak Harapan Jaya, Kecamatan Deli Tua, Kabupaten Deli Serdang, Provinsi Sumatera Utara Medan. Penelitian ini berlangsung selama 8 minggu dimulai dari Bulan Maret sampai dengan Mei 2013. 


\section{Bahan dan Alat Penelitian}

Bahan yang digunakan adalah telur ayam kampung sebagai objek penelitian sebanyak 120 butir dengan rata-rata $(47,5 \pm 3,42 \mathrm{~g})$. Air untuk pelembab. Formalin $40 \%$ dan $\mathrm{KMnO}_{4}$ (kalium permanganat) untuk fumigasi mesin tetas. Alkohol 70\% untuk membersihkan kulit telur. Karton/kardus untuk sekat antar telur. Kapas/kain lap untuk membersihkan kulit telur.

Alat yang digunakan adalah mesin tetas sederhana dua unit kapasitas 100 butir/ unit, satu mesin tetas listrik dan satu lagi mesin tetas dengan sumber energi panas gas bio yang dilengkapi dengan Termoregulator untuk menjustifikasi gas bio menjadi sumber energi panas bagi mesin tetas. Hand sprayer untuk fumigasi. Candler untuk peneropongan. Egg tray untuk tempat telur. Thermometer untuk mengukur suhu. Alat tulis untuk mencatat data. Jam beker untuk mengingatkan waktu pemutaran telur. Timbangan skala $2 \mathrm{~kg}$ dengan ketelitian $1 \mathrm{~g}$ untuk menimbang telur, dan satu unit digester.

\section{Metode Penelitian}

Rancangan yang digunakan pada penelitian ini adalah Rancangan Petak Terbagi (Split Plot Design) dengan menggunakan dua faktor yaitu ; Faktor pertama yang dijadikan sebagai petak utama (main plot) adalah jumlah pemutaran telur perhari dalam mesin tetas dengan 3 perlakuan yaitu :

R1 = pemutaran telur 4 kali sehari $1 \times 6$ jam

$\mathrm{R} 2=$ pemutaran telur 6 kali sehari $1 \times 4$ jam

$\mathrm{R} 3=$ pemutaran telur 8 kali sehari $1 \times 3$ jam

Faktor kedua yang dijadikan sebagai anak petak (sub plot) adalah sumber panas.

$\mathrm{P} 1=$ mesin tetas menggunakan lampu listrik sebagai sumber panas

P2 = mesin tetas menggunakan gas bio sebagai sumber panas

Hanafiah (2003), metode linear percobaan yang digunakan adalah :

$$
Y_{\text {yijk }}=\mu+\alpha_{i}+{ }_{j}+(\alpha \beta)_{i j}+\delta_{i k}+\varepsilon_{i j k}
$$

Keterangan :

$\mathrm{Y}_{\mathrm{i} j \mathrm{k}}=$ nilai pengamatan pada taraf ke $\mathrm{i}$ faktor $\mathrm{A}$, taraf ke $\mathrm{j}$ faktor $\mathrm{B}$, dan ulangan ke $\mathrm{k}$.

$\mu \quad=$ nilai tengah umum

$\alpha_{\mathrm{i}} \quad=$ pengaruh pemutaran telur ke $\mathrm{i}$ dari faktor $\mathrm{A}$

$\beta_{\mathrm{j}} \quad=$ pengaruh sumber panas ke $\mathrm{j}$ dari faktor $\mathrm{B}$

$(\alpha \beta)_{\mathrm{ij}}=$ pengaruh interaksi taraf ke $\mathrm{i}$ faktor $\mathrm{A}$ dengan taraf ke $\mathrm{j}$ faktor $\mathrm{B}$

$\delta_{\mathrm{ik}} \quad=$ pengaruh acak untuk petak utama

$\varepsilon_{\mathrm{ijk}} \quad=$ pengaruh acak untuk anak petak. 


\section{Parameter Penelitian}

\section{Fertilitas}

Fertilitas diartikan sebagai persentase telur yang berkembang dengan jumlah telur fertil yang ditetaskan.

Fertilitas $=\frac{\text { Jumlah telur fertil }}{\text { Jumlah telur yang ditetaskan }} \times 100 \%$

Mortalitas

Mortalitas diartikan sebagai persentase telur yang tidak menetas dari sekelompok telur yang ditetaskan.

Mortalitas $=\underline{\text { Jumlah telur yang tidak menetas }} \times 100 \%$

Jumlah telur fertil

\section{Daya tetas / Hatchability}

Daya Tetas diartikan sebagai persentasi telur yang menetas dari sekelompok telur yang ditetaskan.

Daya tetas $=$ Jumlah telur yang menetas $\times 100 \%$

Jumlah telur yang fertil

(Setiadi, 2000). 


\section{HASIL DAN PEMBAHASAN}

\section{Rekapitulasi Hasil Penelitian}

Rekapitulasi hasil penelitian dari pemanfaatan gas bio sebagai sumber energi panas dalam penetasan telur ayam kampung, tertera pada Tabel 1.

Tabel 1. Rekapitulasi hasil penelitian pengaruh frekuensi pemutaran dan sumber panas yang digunakan terhadap fertilitas, mortalitas dan daya tetas telur ayam kampung.

\begin{tabular}{|c|c|c|c|}
\hline Perlakuan & Fertilitas (\%) & Mortalitas (\%) & Daya Tetas $(\%)$ \\
\hline \multicolumn{4}{|l|}{ Frekuensi Pemutaran: } \\
\hline $\mathrm{R} 1$ & 100 & $30,00^{\mathrm{a}}$ & $70,00^{\mathrm{a}}$ \\
\hline $\mathrm{R} 2$ & 100 & $15,00^{\mathrm{b}}$ & $85,00^{\mathrm{b}}$ \\
\hline R3 & 100 & $7,50^{\mathrm{c}}$ & $92,50^{\mathrm{c}}$ \\
\hline \multicolumn{4}{|l|}{ Sumber Panas: } \\
\hline $\mathrm{P} 1$ & 100 & $18,33^{\text {tn }}$ & $81,67^{\text {tn }}$ \\
\hline $\mathrm{P} 2$ & 100 & $16,67^{\text {tn }}$ & $83,33^{\text {tn }}$ \\
\hline \multicolumn{4}{|l|}{ Interaksi: } \\
\hline $\mathrm{R} 1 \mathrm{P} 1$ & 100 & $30,00^{\text {tn }}$ & $70,00^{\operatorname{tn}}$ \\
\hline $\mathrm{R} 1 \mathrm{P} 2$ & 100 & $30,00^{\text {tn }}$ & $70,00^{\text {tn }}$ \\
\hline $\mathrm{R} 2 \mathrm{P} 1$ & 100 & $15,00^{\text {tn }}$ & $85,00^{\text {tn }}$ \\
\hline $\mathrm{R} 2 \mathrm{P} 2$ & 100 & $15,00^{\text {tn }}$ & $85,00^{\text {tn }}$ \\
\hline R3P1 & 100 & $10,00^{\text {tn }}$ & $90,00^{\text {tn }}$ \\
\hline $\mathrm{R} 3 \mathrm{P} 2$ & 100 & $5,00^{\text {tn }}$ & $95,00^{\text {tn }}$ \\
\hline $\begin{array}{r}\text { Keterangan }:{ }^{\mathrm{a}, \mathrm{b}, \mathrm{c}} \text { Superkrip y } \\
\text { tn : tidak nyata } \\
\mathrm{R} 1, \mathrm{R} 2, \mathrm{R} 3=\mathrm{p} \\
\mathrm{P} 1=\text { Panas list }\end{array}$ & $\begin{array}{l}\text { elur (4 kali/hari, } \\
=\text { Panas Gas bio }\end{array}$ & $\begin{array}{l}\text { nunjukan perbed } \\
\text { dan } 8 \text { kali/hari). }\end{array}$ & ng nyata $(\mathrm{P}>0,05)$ \\
\hline
\end{tabular}

\section{Fertilitas}

Fertilitas diartikan sebagai persentase jumlah telur fertil berdasarkan jumlah telur yang ditetaskan (Setiadi, 2000). Hasil penelitian menunjukkan bahwa fertilitas telur tetas sebesar $100 \%$, sehingga tidak perlu dilakukan analisis ragam. Tingginya angka fertilitas karena telur tetas diperoleh dari peternakan yang sudah memiliki breeding farm sendiri dan sudah mahir dalam memilih dan melakukan penetasan. Hal ini sesuai dengan pernyataan Tarigan (2006), yang menyatakan bahwa untuk memperoleh fertilitas yang telur tetas yang tinggi biasanya diperoleh dari peternakan yang sudah memiliki breeding farm sendiri dan sudah mahir dalam memilih dan melakukan penetasan.

Tinggi rendahnya fertilitas telur tetas dipengaruhi beberapa faktor diantaranya mortilitas sperma, umur induk (jantan dan betina) produksi sperma, ransum perbandingan jantan dan betina, lama penyinaran dan lain sebagainya. Hal ini sesuai dengan pernyataan Kartasudjana dan Suprijatna (2002), yang menyatakan bahwa banyak hal yang 
mempengaruhi fertilitas telur tetas diantaranya ransum, ransum erat hubungannya dengan produksi ternak tak terkecuali produksi sperma, produksi sperma akan tereduksi akibat kekurangan jumlah makanan atau defisiensi suatu zat makanan. Misalnya jika ransum kekurangan vitamin E maka akan menyebabkan sterilitas pada jantan. Oleh karena itu kualitas dan kuantitas ransum harus baik.

Selain hal di atas ada hal lain yang sangat penting dalam menentukan fertilitas telur tetas yaitu lama penyimpanan, semakin lama telur tetas disimpan maka akan menurunkan fertilitas dan daya tetas. Hal ini sesuai dengan pernyataan Iman et al., (2011), telur sebaiknya tidak disimpan lebih dari satu minggu sebab penyimpanan yang semakin lama akan mengurangi fertilitas daya tetasnya dan menyebabkan bertambahnya waktu yang diperlukan untuk menetas.

Fertilitas telur erat hubungannya dengan mesin tetas yang digunakan sebagai tempat penetasan telur, karena selain sumber panas dan jumlah frekuensi pemutaran yang digunakan mesin tetas harus dalam keadaan baik dan dapat menyediakan panas bagi telur. Hal ini sesuai dengan pernyataan Paimin (2004), yang menyatakan bahwa mesin tetas mempengaruhi langsung dalam penetasan telur sebagai penyedia panas bagi telur agar proses penetasan berjalan baik.

\section{Mortalitas}

Mortalitas diartikan sebagai jumlah telur yang tidak menetas dari sejumlah telur fertil yang dimasukkan (Setiadi, 2000). Mortalitas selalu berbanding terbalik dengan daya tetas, oleh karena itu pada suatu penetasan yang baik adalah bila daya tetasnya tinggi yang secara otomatis menyebabkan mortalitasnya rendah.

Hasil penelitian juga menunjukkan bahwa rataan mortalitas telur tetas ayam kampung adalah sebesar $17,5 \%$. Hal tersebut sudah cukup baik karena rata-rata mortalitas pada mesin tetas semiotomatis mencapai 20\%. Hal ini sesuai dengan pernyataan Smith (2000), yang menyatakan bahwa dalam usaha penetasan mortalitas sampai $20 \%$ sudah menguntungkan bagi peternak.

Hasil analisis ragam menunjukkan bahwa pada perlakuan frekuensi pemutaran telur memberikan hasil yang berbeda nyata $(\mathrm{P}>0,05)$, dari Tabel 1 diperoleh bahwa mortalitas tertinggi pada R1 (pemutaran 4 kali/hari) sebesar 30\% dan yang terendah pada perlakuan R3 (pemutaran 8 kali/hari) sebesar 7,5\%. Pada perlakuan sumber panas yang digunakan memberikan hasil yang tidak berbeda nyata $(\mathrm{P}>0,05)$. Hasil penelitian menunjukan bahwa 
frekuensi pemutaran telur dapat menurunkan angka mortalitas telur, hal ini berarti bahwa mesin tetas dengan sumber panas listrik sama baiknya dengan gas bio dan frekuensi pemutaran $8 \mathrm{kali} /$ hari masih lebih baik dibandingkan dengan pemutaran 4-6 kali/hari, akan tetapi pemutaran 4-8 kali/hari masih memberikan nilai mortalitas yang wajar. Hal ini sesuai dengan pernyataan Rasyaf (1995), yang mengemukakan bahwa pemutaran telur sebaiknya dilaksanakan paling sedikit 2 kali atau lebih baik diputar 6, 8 sampai 12 kali sehari dengan setengah putaran, karena dengan diputar sampai 8 kali/hari pemerataan panas lebih rata.

Semakin banyak dilakukan pemutaran maka dapat menurunkan angka mortalitas telur. Hal sesuai dengan pernyataan Tarigan (2006), yang menyatakan bahwa pengaruh frekuensi pemutaran telur terhadap mortalitas dapat dilihat bahwa semakin banyak dilakukan pemutaran maka semakin rendah angka mortalitasnya. Pada penelitian ini pengaruh frekuensi pemutaran telur menurunkan mortalitas sebesar $2,5 \%$.

Faktor-faktor yang mempengaruhi mortalitas sama dengan faktor-faktor yang mempengaruhi daya tetas seperti lama penyimpanan telur dan manajemen penetasan serta keadaan telur. Keadaan telur yang dimaksud adalah bersih, halus dan rata, serta tidak retak dan jangan lebih dari 3 hari. Hal ini diperkuat dengan pernyataan Chairani (2007), yang menyatakan bahwa dalam memilih telur yang baik untuk ditetaskan adalah telur yang bersih, halus dan rata, memilih telur yang warnanya tidak terlalu pekat, bintik di kulit telur harus jelas, kulit telur tidak retak, memilih telur yang baru dan tidak lebih dari 3 hari.

Tingginya angka mortalitas pada mesin tetas listrik dibanding gas bio karena listrik di Sumatera Utara dayanya tidak stabil dan kadang mati sehingga kestabilan suhu panas dalam mesin tetas berkurang. Hal ini sesuai dengan pernyataan Suprijatna (2005), menyatakan bahwa panas dalam inkubator penetasan berpengaruh positif terhadap daya mortalitas, apabila suhu dalam penetasan tidak stabil maka akan meningkatkan angka mortalitas.

Kotoran ternak (ruminansia) sebagai sumber energi panas mempunyai kestabilan suhu panas sehingga dapat dipergunakan dalam berbagai aktifitas manusia. Gas bio adalah campuran beberapa gas hasil perombakan bahan organik oleh mikroorganisme pada kondisi tanpa udara (anaerobik), dimana metan $\left(\mathrm{CH}_{4}\right)$ dan karbon dioksida $\left(\mathrm{CO}_{2}\right)$ merupakan komponen gas terbanyak. Sebagai sumber energi, gas bi dapat dibakar dengan nilai kalor tinggi yaitu pada kisaran 4700-5000 kkal/ $\mathrm{m}^{3}$ (Tarigan, 2009). Nilai kalor gas bio ditentukan oleh perbandingan gas metan $\left(\mathrm{CH}_{4}\right)$, terhadap karbon dioksida $\left(\mathrm{CO}_{2}\right)$. Semakin tinggi persentase gas metan maka nilai kalor biogas tersebut pun semakin tinggi. Intinya gas bio memiliki nilai kalor 4700-5000 kcaI/ $\mathrm{m}^{3}$ dengan komposisi volume $50-60 \% \mathrm{Cl}$ dan40-50\% 
$\mathrm{CO}_{2}$, dengan kestabilan suhu pada gas bio dan gas selalu tersedia sehingga mengurangi angka mortalitas pada telur tetas (Armansyah et al., yang disitasi oleh Ginting, 2009). Ilustrasi pengaruh sumber panas dengan frekuensi pemutaran telur terhadap mortalitas tersaji pada Gambar 1.

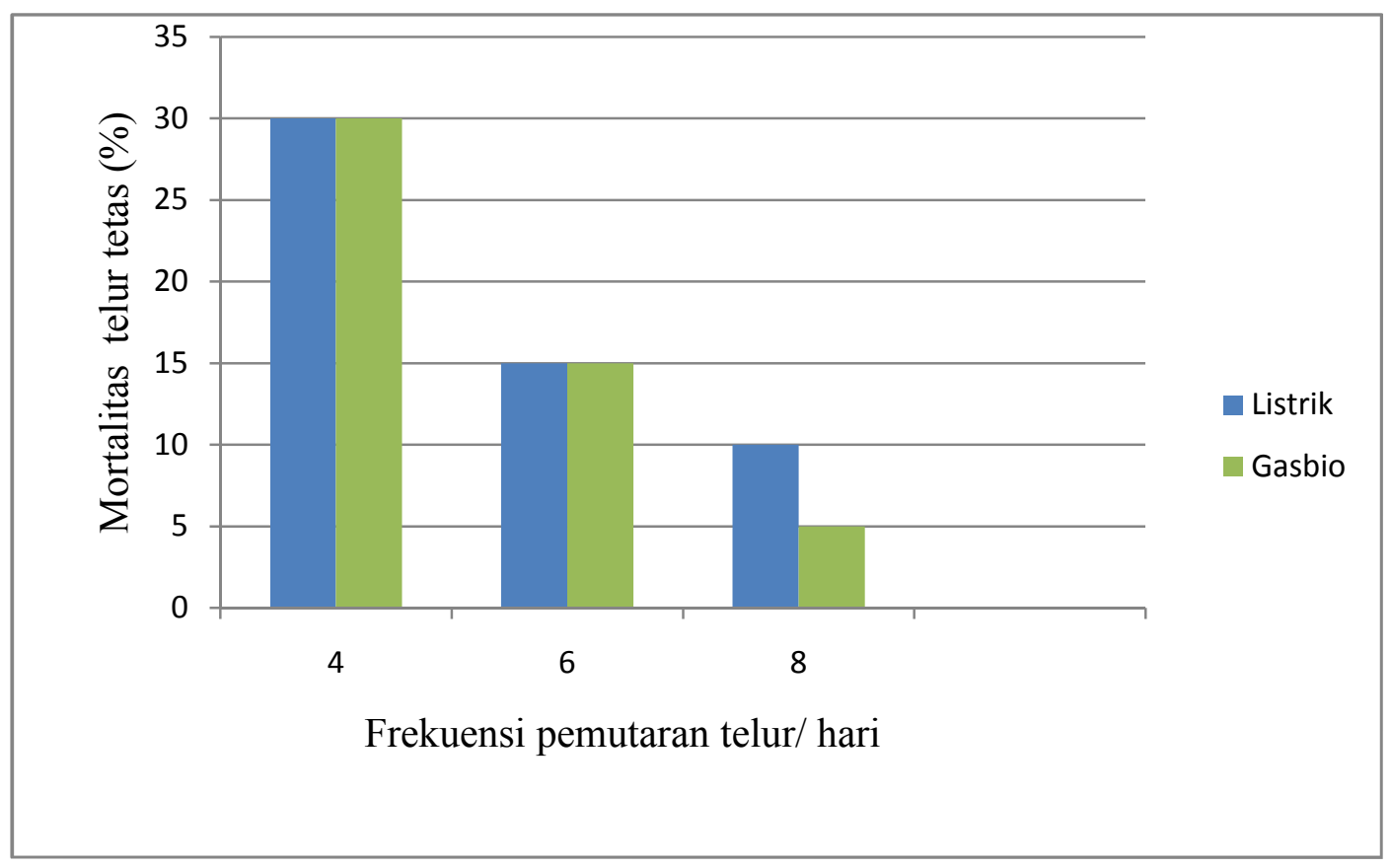

Gambar 1. Histogram mortalitas ayam kampung dengan frekuensi pemutaran dan sumber panas yang digunakan.

Hasil analisis ragam menunjukkan bahwa frekuensi pemutaran telur memberikan pengaruh yang nyata berbeda sedangkan sumber panas yang digunakan dan interaksi keduanya ternyata tidak nyata pengaruhnya terhadap mortalitas telur ayam kampung.

\section{Daya Tetas}

Daya tetas diartikan sebagai jumlah telur yang menetas dari sejumlah telur fertil yang dimasukkan (Setiadi, 2000). Dari hasil penelitian diperoleh bahwa rataan daya tetas telur tetas ayam kampung selama penelitian adalah sebesar $82,5 \%$. Hal ini sejalan dengan pernyataan Marhiyanto (2000), yang menyatakan bahwa dalam penetasan telur, daya tetas $75-80 \%$ sudah sangat menguntungkan karena peternak kurang mengontrol proses penetasan. Menurut Paimin (2004), menyatakan bahwa penetasan yang berhasil dan menguntungkan bagi peternak sekitar $80-90 \%$ karena sudah menggunakan mesin tetas yang modern selama penetasan. 
Hasil analisis ragam menunjukkan bahwa pada perlakuan frekuensi pemutaran telur memberikan hasil yang berbeda nyata $(\mathrm{P}>0,05)$, dari Tabel 1 diperoleh bahwa daya tetas tertinggi pada R3 (pemutaran 8 kali/hari) sebesar 92,5\% dan yang terendah pada perlakuan R1 (pemutaran 4 kali/hari) sebesar 70\%. Pada perlakuan sumber panas yang digunakan memberikan hasil yang tidak berbeda nyata $(\mathrm{P}>0,05)$. Hasil penelitian menunjukan bahwa frekuensi pemutaran telur dapat meningkatkan angka daya tetas telur, hal ini berarti bahwa mesin tetas dengan sumber panas listrik sama baiknya dengan gas bio dan frekuensi pemutaran $8 \mathrm{kali} / \mathrm{hari}$ masih lebih baik dibandingkan dengan pemutaran 4-6 kali/hari, akan tetapi pemutaran 4-8 kali/hari masih memberikan angka daya tetas yang wajar, akan tetapi dapat disimpulkan bahwa pengaruh frekuensi pemutaran telur terhadap daya tetas yaitu menurunnya daya tetas telur seiring dengan semakin jarangnya dilakukan pemutaran terhadap telur, sehingga menyebabkan semakin rendah angka daya tetasnya. Hal ini sejalan dengan pernyataan Siregar, (1996), yang menyatakan bahwa pemutaran telur mempunyai efek langsung dengan kematian embrio, bila pemutaran dilakukan sedikit sekali selama penetasan akan mengakibatkan kematian embrio yang tinggi dibandingkan dengan pemutaran yang lebih banyak.

Hasil penelitian menunjukkan bahwa perlakuan frekuensi pemutaran telur sampai 8 kali/hari memberikan nilai daya tetas yang ternyata lebih tinggi dibandingkan dengan pemutaran 4-6 kali/hari. Hal ini menunjukkan bahwa frekuensi pemutaran telur sangat berpengaruh karena suhu yang diterima pada kulit telur masih kurang merata. Semakin sering diputar maka daya tetasnya semakin tinggi. Hal ini sesuai dengan penyataan Mudsan (2000), mengatakan bahwa pemutaran telur berpengaruh sangat besar bagi daya tetas telur tersebut, karena pemutaran telur menyebabkan meratanya penerimaan suhu pada permukaan kerabang dan juga untuk mencegah penempelan embrio pada kulit telur dan menyebabkan kematian pada embrio. Hasil penelitian menunjukkan bahwa sumber panas dan frekuensi pemutaran telur menaikkan daya tetas sebesar 12,5\%. Sugandono (2001), menyatakan bahwa pemutaran telur merupakan salah satu faktor penentu keberhasilan penetasan. Pemutaran telur 3-5 kali sehari sudah menguntungkan dengan daya tetas telur yang cukup tinggi, kemudian Mudsan (2000), mengatakan bahwa pemutaran telur sampai 8 kali sehari dapat meningkatkan daya tetas telur.

Hasil penelitian menunjukkan bahwa perlakuan sumber panas yang digunakan memberikan pengaruh yang tidak berbeda nyata terhadap daya tetas telur, tidak berbedanya nyatanya daya tetas telur diduga karena suhu yang diterima pada kulit telur sudah merata 
diterima oleh cangkang telur. Ilustrasi pengaruh sumber panas dengan frekuensi pemutaran telur terhadap daya tetas tersaji pada Gambar 2.

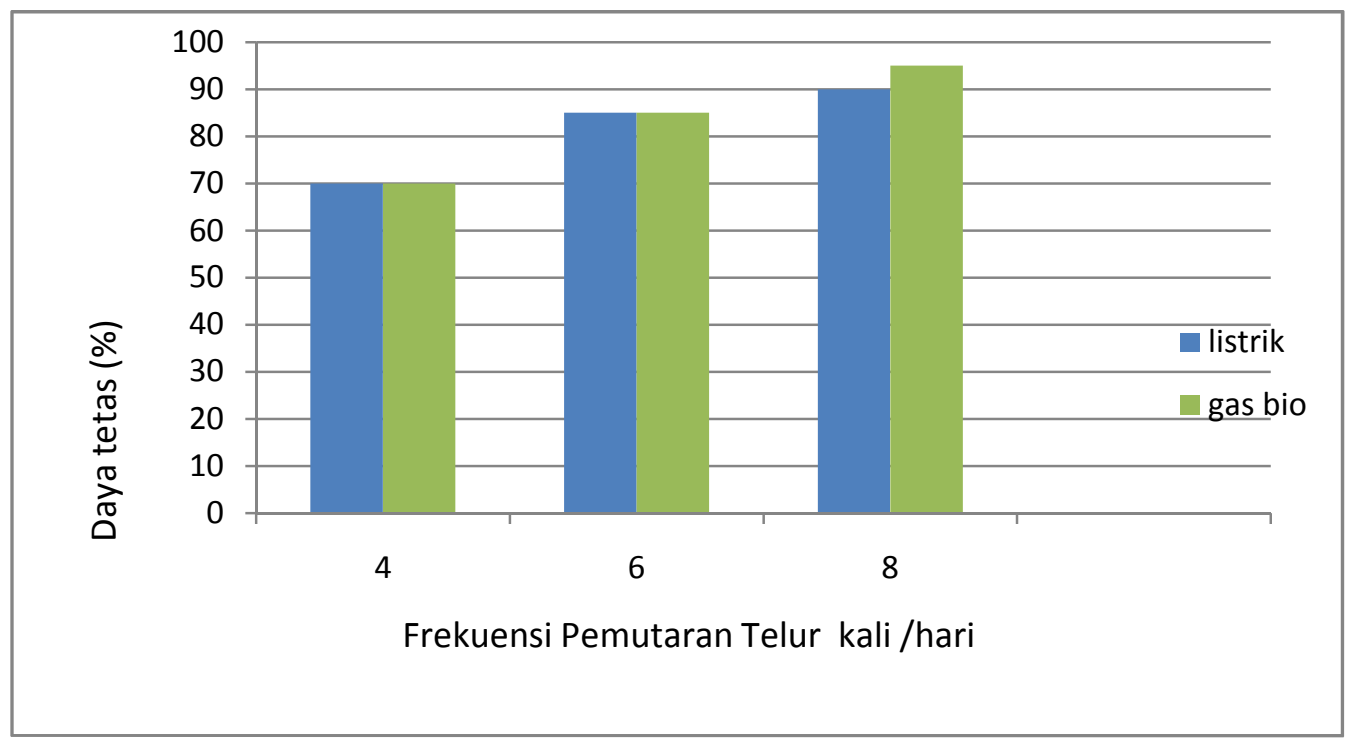

Gambar 2. Histogram daya tetas ayam kampung dengan frekuensi pemutaran dan sumber panas yang digunakan.

Penggunaan mesin tetas listrik menghasilkan rataan daya tetas sebesar 81,67\%, sedangkan dengan gas bio menghasilkan daya tetas sebesar 83,33\%, terdapat selisih rataan daya tetas sebesar $1,67 \%$. Hal ini diduga karena pada mesin tetas listrik pernah terjadi pemadaman listrik, sedangkan yang menggunakan gas bio panas yang dihasilkan selalu stabil. Tingginya angka daya tetas pada gas bio dikarenakan gas bio sebagai renewable energy memiliki suhu yang relatif stabil dengan melakukan pengisian bahan baku (kotoran ternak) ke dalam digester setiap harinya. Hal ini sesuai dengan pernyataan Ginting (2010), untuk mendapatkan gas yang stabil dalam digester maka perlu dilakukan pengisian bahan baku setiap harinya dan mikroorganisme yang ada dalam digester memerlukan makanan untuk hidup dan berkembang biak.

Gas bio dihasilkan oleh proses pemecahan bahan limbah organik yang melibatkan aktivitas bakteri anaerob dalam kondisi anaerobik dalam suatu digester. Pada dasarnya proses pencernaan anaerob berlangsung atas tiga tahap yaitu hidrolisis, pengasaman dan metanogenik. Proses fermentasi memerlukan kondisi tertentu seperti rasio C:N, temperatur, keasaman juga jenis digester yang dipergunakan. Kondisi optimum yaitu pada temperatur sekitar $32-35^{\circ} \mathrm{C}$ atau $\quad 50-55^{\circ} \mathrm{C}$ dan $\mathrm{pH}$ antara $6,8-8$. Pada kondisi ini proses pencernaan mengubah bahan organik dengan adanya air menjadi energi gas. Gas bio umumnya 
mengandung gas metan $\left(\mathrm{CH}_{4}\right)$ sekitar $60-70 \%$ yang bila dibakar akan menghasilkan energi panas sekitar 1000 British Thermal Unit/ft3 atau $252 \mathrm{Kkal} / 0,028 \mathrm{~m}^{3}$ (Haryati, 2006).

Teknologi biometanisasi dimanfaatkan untuk menghasilkan energi. Gallert dan Winter (2002), menyatakan bahwa bakteri flora yang kompleks bekerja dalam proses perombakan biomas menjadi gas bio, gas bio inilah yang dapat digunakan manusia untuk segala aktifitasnya termasuk penetasan. Menurut Ginting (2010), bahwasanya $1 \mathrm{~kg}$ kotoran sapi akan menghasilkan 40-46 liter gas yang dapat langsung digunakan untuk berbagai kegiatan.

Listrik dan gas bio kedua sumber panas ini dapat digunakan sebagai sumber panas dalam penetasan telur. Listrik yang tidak stabil dapat menurunkan daya tetas telur kecuali menggunakan alat lain seperti genset, akan tetapi dengan menggunakan gas bio suhu dan panas yang dihasilkan dapat stabil dengan cara selalu diisi setiap hari, meskipun pada saat volume gas susut dan tekanan gas melemah tetapi masih dapat digunakan dalam proses penetasan.

Hasil analisis ragam menunjukkan bahwa frekuensi pemutaran telur memberikan pengaruh yang nyata berbeda sedangkan sumber panas yang digunakan dan interaksi keduanya ternyata tidak nyata pengaruhnya terhadap daya tetas telur ayam kampung.

\section{KESIMPULAN}

Berdasarkan hasil penelitian, pemanfaatan gas bio sebagai sumber energi panas alternatif pada mesin tetas sama baiknya dengan menggunakan mesin tetas sumber energi listrik untuk meningkatkan fertilitas dan daya tetas telur ayam kampung, dan pemutaran 8 kali/hari dapat meningkatkan daya tetas telur.

\section{DAFTAR PUSTAKA}

Chairani, 2007. Pengujian Mineral Esensial dalam Ransum terhadap Fertilitas, Daya Tetas, Mortalitas dan perbandingan Jenis Kelamin Jantan dan Betina Burung Puyuh (coturnix-coturnix japonica). Agripet, Vol. 3 No. 1. April 2007. Hal 16-22. Departemen Peternakan, Universitas Sumatera Utara. Medan.

Gallert, C dan J. Winter. 2002. Solid and liguid residues as raw materials for biotechnology. Naturwissenchapeften (2002) 89;483-496.

Ginting, N. 2010. Pemanfaatan Limbah Pemotongan Hewan yang Berkelanjutan. Disertasi. Sekolah Pasca Sarjana USU. Medan.

Haryati, T. 2006. Limbah Peternakan yang Menjadi Sumber Energi Alternatif. Balai Penelian Ternak. Bogor. 
Hanafiah, K.A., 2003. Rancangan Percobaan. Fakultas Pertanian. Universitas Sriwijaya. Palembang.

Iman, R., Suroprawiro dan M. Sabrani, 2011. Teknik Beternak Ayam Ras di Indonesia, Margie Group. Jakarta.

Kartasudjana dan Suprijatna. 2010. Manajemen Ternak Unggas. Penebar Swadaya. Jakarta.

Marhiyanto, B. 2000. Sukses beternak ayam arab. Difa Publisher. Jakarta.

Mudsan, M. 2000. Usaha Penetasan Telur. Karya Anda. Surabaya.

Murtidjo, B. A. 2002. Mengelola Ayam Buras. Kanisius. Yogyakarta.

Kartasudjana, Ruhyat dan Suprijatna, E. 2010. Manejemen Ternak Unggas. Penebar Swadaya. Jakarta.

Nukulchai, W. Nanok., and Austriaco. L. Robles, 1985. Ferrocement biogas digester. International Ferrocement Center. Kluwer Academic Publisher. Netherlands.

Paimin, F.B. 2004. Membuat dan Mengelola Mesin Tetas. Penebar Swadaya. Jakarta.

Rasyaf, M. 1995. Penggelolaan Produksi Telur. Cetakan ke IV. Kanisius. Yogyakarta.

Setiadi, P. 2000. Pengaruh Indeks Bentuk Telur Terhadap Persentase Kematian Embrio, Gagal Tetas dan DOD Cacat Pada Itik Tegal yang Diseleksi. Animal Production. Vol. 2 No. 1. Januari 2000. Hal 80-86. Faculty of Animal Husbandry. Jendral Soedirman University. Purwokerto.

Smith, W. T. 2000. Hatching quality Chiks. Extension Service of Mississippi State University.

Siregar. 1996. Kotoran sebagai sumber energy. Dewaruci Press. Jakarta.

Sugandono, B. 2001. Ilmu Unggas Air. Gadjah Mada University Press. Yogyakarta.

Suprijatna, E. 2005. Ayam Buras Krosing Petelur, Penebar Swadaya. Jakarta.

Tarigan, M. 2006. Pengaruh Frekuensi Pemutaran Telur Terhadap Daya Tetas dan Bobot Badan DOC Ayam Kampung. Skripsi. Departemen Peternakan. USU. Medan.

Tarigan, R. 2009. Pemanfaatan Biogas Kotoran Ternak Sapi Sebagai Pengganti Bahan Bakar Minyak Dan Gas. Tesis. Sekolah Pasca Sarjana USU Press. Medan. 